\title{
Identifying the structure of students' argumentation in covariational reasoning of constructing graphs
}

\author{
Sutini $^{1}$, Iffana Fitrotul Aaidati ${ }^{1}$, Kusaeri ${ }^{1}$
}

\begin{abstract}
Abstrak: Penelitian ini bertujuan untuk mengidentifikasi klaim, bukti, dan alasan siswa pada penalaran kovariasional dalam mengonstruk grafik fungsi. Penalaran kovariasional merupakan salah satu pendekatan dalam menyelesaikan permasalahan fungsi. Penelitian ini melibatkan 30 siswa kelas 11. Pengumpulan data dilakukan menggunakan tes kovariasi dan wawancara. Data hasil hasil tes kovariasi siswa dikelompokkan berdasarkan kriteria aksi mental penalaran kovariasional (Carlson et al., 2002), kemudian dipilih siswa yang mampu menyelesaikan minimal dua soal kovariasi. Data hasil wawancara dianalisis untuk mengonfirmasi dan menggali lebih dalam argumentasi siswa. Hasil penelitian menunjukkan hanya satu siswa yang memenuhi lima aksi mental penalaran kovariasional sedangkan ketiga siswa lain memiliki persamaan komponen argumentasi yang tidak memenuhi aksi mental. Untuk ketiga siswa tersebut, klaim dan alasan yang digunakan dalam membangun grafik fungsi tidak berada pada aksi mental 5 sedangkan bukti tidak berada pada aksi mental 3 (koordinasi besar perubahan), aksi mental 4 (koordinasi laju perubahan rata-rata), dan aksi mental 5 (koordinasi laju perubahan sesaat).
\end{abstract}

Kata kunci: Argumentasi, Klaim, Bukti, Alasan, Penalaran kovariasional

\begin{abstract}
This study aimed to identify students' claim, evidence, and reasoning in covariational reasoning of constructing the graphs of a function. Covariational reasoning is one of the approaches to solve the problems of function. The study involved thirty grade 11 students. Data was collected through a covariation test and interview. The results of the test were grouped based on the criteria of mental action of covariational reasoning (Carlson et al., 2002), then the students who solve correctly two or three problems in the test were selected as the subjects. The interview data were analyzed to confirm and further dig students' structure of argumentation. The findings of this study indicate that only one student fulfils five mental actions of covariational reasoning; meanwhile, the other three students have similar components of argumentation which do not meet the mental actions. The claim and reasoning used by the latter students in covariational reasoning to construct graph are not identified in mental action 5 and the evidence is not found in mental action 3 (major coordination of change), mental action 4 (coordination the average rate of change), and mental action 5 (coordination of the instantaneous rate of change).
\end{abstract}

Keywords: Argumentation, Claim, Evidence, Reasoning, Covariational reasoning

\section{A. Introduction}

Students' argumentation could indicate their conceptual understanding or reasoning (Heng, Surif, \& Seng, 2014). Similarly, Soekisno (2015) asserts that mathematics argumentation is a feasible method to examine students' ability in problem-solving. Number pattern is one of the

\footnotetext{
${ }^{1}$ Department of Mathematics Education, Universitas Islam Negeri Sunan Ampel Surabaya, Jln. A. Yani No. 117, Surabaya, Indonesia, sutini@uinsby.ac.id
} 
mathematics problems which require argumentation (Sadieda et al., 2018). Furthermore, Cross et al. (2008) argue that argumentation support students' understanding of a concept and extend their knowledge by achieving know ideas. Argumentation involves reasoning which can be used to draw a conclusion of the given information and creative thinking to make an evidence-based statement (Pallant \& Lee, 2015). The construction of argument demands cognitive involvement, such as analyzing and understanding data, providing an explanation, supporting ideas, and rebut the validity of an idea, all of which include in reasoning (Heng, Surif, \& Seng, 2014). It shows the relation between argumentation and reasoning.

The reasoning is an important tool to learn mathematics (Baroody, 1993). In the Indonesian school curriculum, known as K13, the students are expected to be able to have reasoning and present the topic either in concrete or abstract ways (Depdiknas, 2013). Also, NCTM (2000) underlines that students should be encouraged to reason and think analytically, make and investigate mathematics conjectures, develop and evaluate mathematics argument and proof, and use various kinds of reasoning. Reasoning comprises basic thinking, critical thinking, and creative thinking (Subanji, 2011). Thus it is categorized as high order thinking (HOT). HOT skills are essential in problem-solving, especially problems given in the form of a project (Kusaeri et al., 2019). In conclusion, reasoning plays a paramount role for students in solving mathematics problems.

Zeytun, Cetinkaya, and Erbas (2010) found that teachers' prediction about students' reasoning is limited by teachers' thought regarding the problems given to the students. A part of teacher and learning environment which discourage the emergent of students' reasoning, the students also contribute to this condition- they are not used to reasoning properly in the classroom. Students often solve the mathematics problems as if they were following the process of reasoning, but actually, they did not. It is called as pseudo-reasoning (Subanji, 2011). This process makes students have an incorrect perception of reasoning. Thus, to develop students' reasoning, a learning environment which provides a vast opportunity for students to get used to reasoning is required.

The topic of function in the schools is used to introducing to students using correspondence approach which base on the abstract definition, a bit narrow, and focus on the explicit rules (Confrey \& Smith, 1994). This approach leads students to pay much attention to the rules or formulas and procedures to describe output values from known input values since students are provided with notations, manipulations, and the formula of function (Umah, As'ari, \& Sulandra, 2016). Learning which centres on procedural rules will weaken the students' reasoning (Kusaeri \& Aditomo, 2019).

Covariation approach is an alternative approach to teach function which differs from a convergence approach (Subanji, 2011). It pinpoints to the relation of two structured quantities in the form of algebra, visual in a graph, or real-life situation (Confrey \& Smith, 1995). Besides, it focuses on the ability to form the expression of two varied quantities and coordinate the changes within its relation. Covariational does not only confine procedural rules but also include the reasoning (Thompson \& Carlson, 2017). In this case, this approach is more appropriate to support students' reasoning when solving problems involving the graph of a function.

Covariational is defined as the coordination of several quantities, and the change of one quantity causes the change of another quantity (Clement, 1989; Carlson et al., 2002; Koklu, 2007). Slavitt (1997) defines covariational as analyzing, manipulating, and understanding the relationship between changing quantities. Confrey and Smith $(1994,1995)$ and Thompson (1996) even argue that covariational approach is a more intuitive one formally. Subanji (2011) 
explains that constructing graphs requires reasoning on covariational problems. It closely relates to the concept of function as one quantity could be an input (independent variable) and another quantity as the output (dependent variable) (Subanji, 2006). In the present study, covariational approach means students' ability in establishing the image of two different quantities wherein a change in one quantity associates with the change of another one in a specific relation.

The use of the covariational approach in constructing graphs of a dynamic problem can be identified through the levels of covariational reasoning. Carlson et al. (2002) propose mental actions of covariation framework- from mental action 1 (MA1) to mental action 5 (MA5). MA1 (initial coordination) is coordinating the value of one quantity or variable with changes in the other variable. MA2 (the coordination of the direction of change) is coordinating the direction of change of one variable with changes in the other variable. MA3 (major coordination of change) is coordinating the amount of change of one variable with changes in the other variable. MA4 (coordination of average rate of change) is coordinating the average rate of change of the function with uniform increments of change in the input variable. MA5 (the instantaneous rate of change) is coordinating the instantaneous rate of change of the function with continuous changes in the independent variable for the all domain of the function.

Mental actions of covariational reasoning are developed through various arguments (Umah et al., 2016). Each established argument has structure or components which can be utilized to analyze the argument itself (Fischer et al., 2014). The are several models of argumentation employed to analyze covariational reasoning, for example, Toulmin (2003) and McNeill and Krajcik (2011). Toulmin's model comprises detail basic structure of argumentation and covers various informal argumentations. However, Umah et al., (2016) found that the model did not suit students' ability since the students could only provide data, backing, warrant, and conclusion. Moreover, Inglis, Mejia-Ramos, and Simpson (2007) assert that rebuttal and modal qualifier differentiate between the amateur and advanced mathematicians in using non-formal arguments. The expert tends to focus on the two to make a claim. On the other hand, McNeill and Krajcik's model of argumentation has been adjusted to students' ability; thus, it is easier and more applicable to analyze students' argumentation.

McNeill and Krajcik (2011) further develop Toulmin's model of argumentation to support students involved in a simpler mode of argumentation. It consists of a claim, evidence, reasoning, and rebuttal (McNeill \& Krajcik, 2011). A claim is a statement or conjecture which explains a question or a phenomenon (McNeill \& Krajcik, 2008; Berland \& McNeill, 2010). Evidence is quantitative or qualitative data to answer the question, solve problems, or to decide (Aikenhead, 2005). It can be proof to support a claim. The reasoning is an explanation of why a proof could support a claim (McNeill et al., 2006). The rebuttal is the alternative claim which provides a counter-proof and reason why the existing claim cannot stand (McNeill \& Martin, 2011). McNeill and Krajcik's argumentation could be used to improve verbal and writing argumentation (Sadieda, 2019). It is also promising to analyze formal and informal argumentation (Umah et al., 2016). Students apply formal argumentation to represent their mathematical argumentations in the form of writing. Meanwhile, informal argumentations refer to students' verbal words. In this case, the argumentation model which accommodate both kinds of argumentations.

Prior studies (e.g., McNeill \& Martin, 2011; Sadieda, 2019) have used McNeill and Krajcik's argumentation. Sadieda (2019) analyzed the students' argumentation in proving subgroup problems. McNeill and Martin (2011) used the model as a rubric to examine the strength and weakness of students' argumentation about the lever. However, the foregoing studies have 
not addressed covariational reasoning. Several authors (e.g., Umah et al., 2016; Santoso, Budiarta, \& Sulaiman, 2019; Rodriguez et al., 2019) studied covariational reasoning, but they used Toulmin's argumentation. The present study identified students' argumentation (claim, evidence, and reasoning which refer to McNeill and Krajcik's model) when constructing a graph of a function in the five levels of students' mental actions of covariational reasoning (Carlson et al., 2002).

\section{B. Methods}

The present study follows a descriptive qualitative approach. Data were collected through covariational reasoning test and interview. The test was adapted from prior studies (Carlson et al., 2002; Koklu, 2007; Stewart, 2008). The first item of the test refers to the bottle problem (Carlson et al., 2002). The second item was taken from one of the covariational problems in calculus book (Stewart, 2008). And the final item was developed from a covariational problem by Koklu (2007).

\section{Problem 1}

Imagine the bottle is filled up with water constantly. Construct a graph in which the height of the water as a function of the amount of water in the bottle! Provide a reason for your answer!

\section{Problem 2}

Orange juice is filled up constantly in the concave glass. Construct a graph in which the height of orange juice as a function of the amount of orange juice in the glass! Provide a reason for your answer!
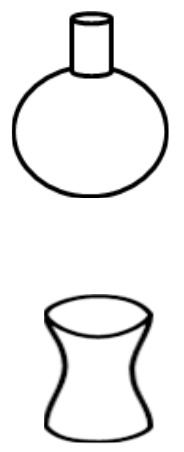

\section{Problem 3}

Two cars from opposite directions run towards each other at a constant speed. The speed of both cars is increasing when their distance is getting closer. After passing through each other, their speed is getting slower. Construct a graph

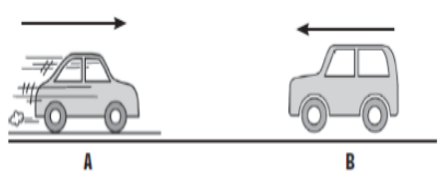
which shows the distance of the two cars as the function of time covered by the cars! Provide a reason for your answer!

This study involved thirty grade 11 students who have learned the graph of a function. They were given the covariation test (Problem 1,2, and 3), then the results were categorized into the fulfilment of mental actions (Table 1). Students' constructed graphs which fulfil all mental actions in two or all problems were selected as the subjects. The criterion actually has a shortage and advantage point. The selection of students' graphs which indicate all mental actions in Table 1 eliminate the chance to examine students' argumentation which could only fulfil the mental actions for one problem, solve the problems but with complete graphs, or even those who could not solve the problems at all. The advantage relates to the data that we could achieve when interviewing the selected subjects with the criteria. It is possible the selected students' graphs 
fulfil the mental actions, but they could not justify their graphs. It provides another insight from this investigation.

Table 1. The description of mental actions of covariational reasoning (adapted from Carlson et al., 2002)

\begin{tabular}{cll}
\hline $\begin{array}{c}\text { Mental } \\
\text { actions }\end{array}$ & \multicolumn{1}{c}{ Description } & \multicolumn{1}{c}{ Actions } \\
\hline 1 & $\begin{array}{l}\text { Coordinate the value of one } \\
\text { variable to the change of another } \\
\text { variable } \\
\begin{array}{l}\text { Coordinate the direction of change } \\
\text { of one variable to the change of } \\
\text { another variable }\end{array}\end{array}$ & $\begin{array}{l}\text { Give a label to the axis by coordinating two } \\
\text { variables. For example, } y \text { changes which } \\
\text { refer to the change of } x\end{array}$ \\
$\begin{array}{l}\text { 1. Construct expanding line } \\
\text { 2. Explain verbally about the change of } \\
\text { output variable relating to the change of } \\
\text { the input variable }\end{array}$ \\
$\begin{array}{l}\text { Coordinate the amount of change of } \\
\text { one variable to the change of } \\
\text { another variable }\end{array}$ & $\begin{array}{l}\text { 1. Make a point or mark on the graph and } \\
\text { plan to construct a secant line }\end{array}$ \\
4 & $\begin{array}{l}\text { 2. Explain verbally about the amount of } \\
\text { change of output variable relating to the } \\
\text { change of the input variable }\end{array}$ \\
$\begin{array}{l}\text { Coordinate the average rate of } \\
\text { change of the function with uniform } \\
\text { variable }\end{array}$ & $\begin{array}{l}\text { 1. Construct secant line which connects the } \\
\text { points which look like a graph }\end{array}$ \\
& $\begin{array}{l}\text { 2. Explain verbally about the rate of change } \\
\text { of output variable (relating to input } \\
\text { variable) while considering uniform } \\
\text { increments of change in the input variable }\end{array}$ \\
$\begin{array}{l}\text { Coordinate the instantaneous rate of } \\
\text { change of the function with } \\
\text { continuous changes in the } \\
\text { independent variable for the all } \\
\text { domain of the function }\end{array}$ & $\begin{array}{l}\text { 1. Construct a smooth curve with a clear } \\
\text { sign of concave changes }\end{array}$ \\
$\begin{array}{l}\text { 2. Explain verbally the instantaneous rate of } \\
\text { change for all domain of the function } \\
\text { (concave direction and turning point are } \\
\text { correct) }\end{array}$
\end{tabular}

After categorizing the results of the test, we had three students who solve two problems (coded as A, B, and C) and all problems (Coded as D). We administered a task-based interview for the subjects to further explore their structure of argumentations (claim, evidence, and reasoning). The role played by the interview in this study is crucial to decide whether or not the subjects fulfil mental actions. Students' claim, evidence, and reasoning are emergent in the mental actions if the constructed graphs specify the mental actions and the students are able to understand and justify the graphs. The interview was guided by the indicators of mental actions of covariational reasoning in Table 2.

Table 2. The indicators of claim, evidence, and reasoning in covariational reasoning

\begin{tabular}{cll}
\hline $\begin{array}{c}\text { Mental } \\
\text { actions }\end{array}$ & Argumentation & \multicolumn{1}{c}{ Description } \\
\hline MA1 & Claim & $\begin{array}{l}\text { The student is able to provide statement or conjecture about } \\
\text { the coordination of the change of the output variable as the } \\
\text { input variable changes. } \\
\text { The student is able to sketch a position and label of each } \\
\text { variable }\end{array}$ \\
\hline
\end{tabular}




\begin{tabular}{|c|c|c|}
\hline $\begin{array}{l}\text { Mental } \\
\text { actions }\end{array}$ & Argumentation & Description \\
\hline \multirow{4}{*}{ MA2 } & Reasoning & $\begin{array}{l}\text { The student is able to explain the relation on the position of } \\
\text { the variables in the graph relating to the change of output } \\
\text { variable as a result of the change of the input variable }\end{array}$ \\
\hline & Claim & $\begin{array}{l}\text { The student is able to provide a statement or conjecture } \\
\text { about the coordination of the change direction of the output } \\
\text { variable when noticing the change in the input variable. }\end{array}$ \\
\hline & Evidence & $\begin{array}{l}\text { The student is able to sketch a graph with upward direction } \\
\text { or positive gradient }\end{array}$ \\
\hline & Reasoning & $\begin{array}{l}\text { The student is able to the relation between the change } \\
\text { direction of the graph and the change of the output variable } \\
\text { as a result of the change of the input variable }\end{array}$ \\
\hline \multirow[t]{3}{*}{ MA3 } & Claim & $\begin{array}{l}\text { The student is able to provide a statement or conjecture } \\
\text { about the amount of the change of the output variable by } \\
\text { considering the change in the input variable. }\end{array}$ \\
\hline & Evidence & The student is able to sketch point and secant line. \\
\hline & Reasoning & $\begin{array}{l}\text { The student is able to explain the relation between a point } \\
\text { made in the graph and the amount of change in the output } \\
\text { variable as a result of the change in the input variable. }\end{array}$ \\
\hline \multirow[t]{3}{*}{ MA4 } & Claim & $\begin{array}{l}\text { The student is able to provide statement or conjecture about } \\
\text { the change rate of the output variable by considering the } \\
\text { constant change in the input variable }\end{array}$ \\
\hline & Evidence & $\begin{array}{l}\text { The student is able to sketch line segments which approach } \\
\text { the graph with different estimated gradients. }\end{array}$ \\
\hline & Reasoning & $\begin{array}{l}\text { The student is able to explain the relationship between the } \\
\text { secant line which has a different gradient and the average } \\
\text { rate of change of output variable as a result of unform } \\
\text { change in the input variable }\end{array}$ \\
\hline \multirow[t]{3}{*}{ MA5 } & Claim & $\begin{array}{l}\text { The student is able to provide statement or conjecture about } \\
\text { the instantaneous rate of change in the decreasing interval } \\
\text { for the entire domain of the function. }\end{array}$ \\
\hline & Evidence & $\begin{array}{l}\text { The student is able to construct a smooth curve with a clear } \\
\text { indicator of change (the concavity point and the turning } \\
\text { point are correct) }\end{array}$ \\
\hline & Reasoning & $\begin{array}{l}\text { The student is able to explain the relation between a } \\
\text { smooth-shaped graph which has some turning points and } \\
\text { instantaneous rate of change of output variable as a result of } \\
\text { the change of input variable withing decreasing interval. }\end{array}$ \\
\hline
\end{tabular}

Data from the interview was analyzed as follows: (1) play the recorded interviews, (2) transcribe the interviews, (3) condensate or reduce the data, and (4) draw a conclusion. In data reduction, students' verbal argumentations were categorized to meet the indicators in Table 2. It is then presented in the transcript 1-6. The reduced interview data was related to subjects' works on the graph in each problem. Eventually, the findings were summarized in Table 3 and conclude accordingly.

\section{Findings and Discussion}

This part presents each subject's works on the covariational test and the excerpt of interview transcripts which indicate their claims, evidence, and reasoning in mental actions of 
covariational reasoning. We then interpret the data to formulate the findings of the present study, as summarized in Table 3. The findings are ultimately discussed to have better insight on students' structure of argumentation and possible future studies.

Transcript 1 shows subject A's responses to the interview of his work on problem 1.

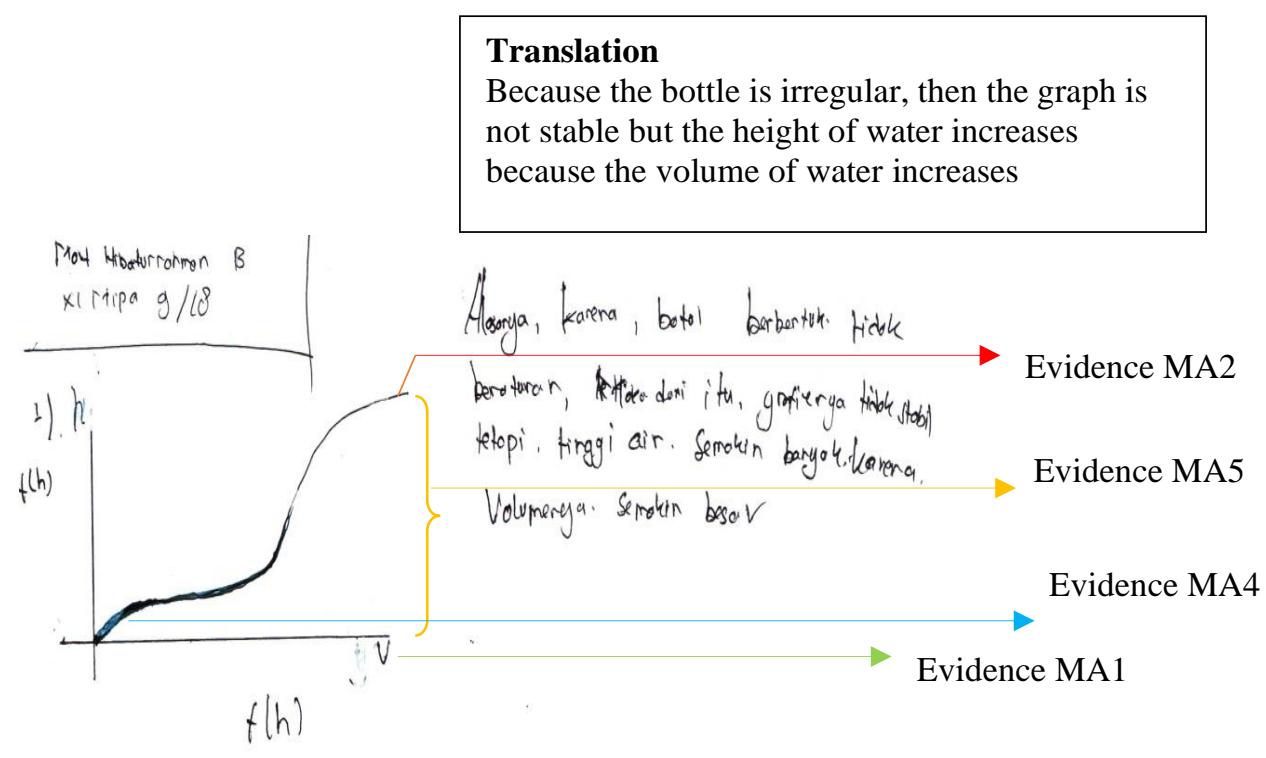

Figure 1. Subject A's graph on problem 1

\section{Transcript 1}

$R \quad: \quad$ What variable do you identify in the problem 1 to construct graph?

$A$ : Volume and the height of the water, respectively as $x$-axis and $y$-axis (Evidence MA1)

$R:$ How the two variables relate?

$A$ : What I understand is the height of water increases when the volume of water also increases (Claim MAl)

$R \quad: \quad$ Is the position of the variables in the graph influence each other?

$A$ : Yes, because of the height of water increases as a result of the increasing volume of water (Reasoning MA1). But, the increase of the height of the water is affected by the irregular form of the bottle (Claim MA3)

$R \quad:$ How did you construct the graph?

A : I just think that if the volume of water continues to increase, the height of water will increase (Claim MA2) in the upward direction like this (Evidence MA2), and because the shape of the bottle is irregular, so the height of water changes unequal, so the shape of the graph is not stable (Reasoning MA3)

$R \quad: \quad$ This upward direction of the graph shows the increase in the height of water? Why?

A : Yes, because if the height of water increases, then the graph goes upward (Reasoning MA2)

$R \quad: \quad$ Before making the graph, you firstly make a point or sign to mark the amount of change of the water height?

$A$ : No, I just make the graph referring to the shape of the bottle.

$R$ : Could you explain the effect of the change of water height caused by continuously filling the same amount of water in the bottle?

$A$ : The changes vary (Claim MA4) like my constructed graph.

$R \quad$ : Why your graph like a smooth curve with some turnings? 
A : I do not know the theory. I just think the water is filled up continuously with the same volume in the irregular bottle. This makes the graph look like that (pointing to the graph) (Reasoning MA4)

Subject A's work on problem 1 (Figure 1) and response in the interview (Transcript 1) reveals that he was able to demonstrate claim on MA1, MA2, MA3, and MA4 of covariational reasoning. However, subject A did not show claim on MA5 since his statement had not met the indicator. He also showed reasoning on MA1, MA2, MA3, and MA4 of covariational reasoning. MA5 was not identified since he did not construct smooth curve-shaped graph as the result of instantaneous rate of change. He only constructed the graph based on fact, which lead to MA4. This is in line with the claim provided which is still in MA4. In this case, although there is proof which supports MA5, the subject was not able to make a statement which meets MA5; thus, the reasoning is not representative.

Figure 1 shows evidence in MA1, MA2, MA4, and MA5 of covariational reasoning. MA3 was not fulfilled since the graph has not shown points used to mark the amount of height change. In the interview, subject A could not explain the existence and function of point to mark the amount of change and as a basis for MA4 and MA5. Thus, he could only reach MA1 and MA2.

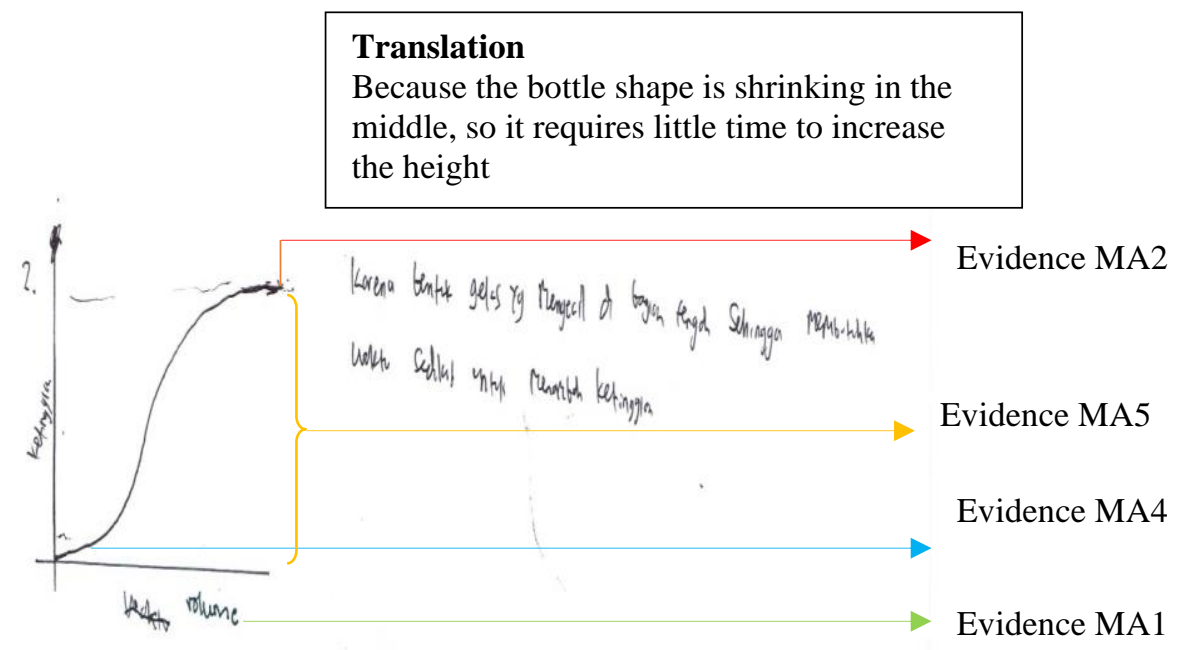

Figure 2. Subject A's graph on problem 2

Transcript 2 shows subject A's responses to his work on problem 2.

\section{Transcript 2}

$R$ : What variable do you identify in the problem 1 to construct graph?

$A$ : The height and volume of juice, the height of juice in $y$-axis and volume in the $x$ axis (Evidence MA1)

$R \quad: \quad$ Do two variables relate? Why?

$A$ : Yes, it relates to each other (Claim MA1) because if the volume increases then the height of juice also increases (Reasoning MA1)

$R \quad$ : What happens to the graph of juice height if the volume of juice is added continuously?

A : The graph goes upward (Claim MA2) as this graph (Evidence MA2)

$R$ : Does the direction of the graph show the direction of the change of juice height? Why? 
A : Yes, because the height of juice keeps increasing, so the graph goes upward (Reasoning MA2)

$R$ : What do you firstly understand when solving this problem?

$A$ : The increasing height of orange juice is affected by the small shape of glass in the middle (Claim MA3)

$R \quad: \quad$ Does the shape of the glass also affect the amount of change to the height of juice? Why?

A : It does, because the amount of change of juice height in the bottom part of the glass is less than in the mid part, and the amount of change of juice height in the mid part of the glass is more than in the bottom and top part of the glass (Reasoning MA3)

$R$ : Could you point your graph which shows the amount of change of juice height!

$A$ : When solving the problem, I constructed a graph following the shape of the glass. I did not think to make a graph which shows the amount of change of juice height

$R \quad: \quad$ What happens to the height of juice considering the volume of juice was continuously filled up with the same amount and in the concave glass?

$A$ : The height of juice increases faster when going to the mid part of the glass, and become slower when reaching the top of the glass (Claim MA4). This makes graph like this (Point to the graph)

$R \quad$ : Why does your graph look like a smooth curve?

A : Similar reason for problem 1

Subject A's work on problem 2 (Figure 2) and responses in the interview (Transcript 2) indicate that subject A on problem 2 demonstrated claim in MA1, MA2, MA3, and MA4 of covariational reasoning. He was not able to provide a proper statement about MA5 although the constructed graph is a smooth curve. His reasoning for problem 2 is similar to problem 1; MA1, MA2, MA3, and MA4.

Figure 2 shows evidence in MA1, MA2, MA4, and MA5. Evidence in MA3 was not identified in the student's graph (Figure 2) since he did not think a point is necessary but directly construct graph referring to the shape of glass without firstly make a point to mark the amount of change. Since the existence of point is not addressed in the interview as a basis for MA4 and MA5, only MA1 and MA2 are reached.

Subject B provided responses to his graph (Figure 3) in the transcript 3.

\section{Transcript 3}

$R \quad: \quad$ What variable do you identify in the problem 1 to construct graph?

$B$ : $x$ as the amount of water and $y$ as the height of water (Evidence MAl). I firstly think the water was filled up into a solid then I imagine after water was continuously added with the same amount, so the increasing height is different at each part (Claim MA4)

$R$ : Why $x$ as the amount of water and $y$ as the height of water?

$B$ : Because the height of the water is the function of the amount of water (Reasoning MAl)

$R \quad:$ How two variables relate?

$B$ : As the input and output in a function, if the input changes then the output will change (Claim MA1). Besides, more water put in the bottle will affect the change of water height in the bottle.

$R \quad: \quad H o w$ is the change direction of the graph if the water is continuously added? 
$B$ : The graph has a positive direction upward (Claim MA2) because when water is continuously added, the amount of water will increase and not decrease, so the graph goes upward (Reasoning MA2)

$R$ : Does the bottle affect the change of water height? Explain!

$B$ : The bottle shape influences the change of water height (Claim MA3) because the bottle is not flat, which cause different surface area. It affects the rate of change of water height that finally form a turning (Reasoning MA4)

$R$ : Could you explain the change of water height at the bottom, mid, and top of the bottle?

$B$ : The change of water height at the bottom is faster than at the mid part, and at the mid part it is becoming slower than at the bottom and top of the bottle (Claim MA4). This is because the bottle is convex (Reasoning AM3) and can be seen from the graph which has turning

$R$ : Before the graph like this (pointing to the graph), did you make a point to mark the amount of change of water height?

$B$ : No, I directly drew it with my estimation

$R \quad: \quad$ Why does your graph look like a smooth curve?

$B$ : Maybe this relates to the rate change (Reasoning MA4), I am not sure, I just follow my intuition.

Translation

Reason: because the shape of the bottle is irregular. Although it is filled up with water constantly, the graph goes high toward the amount of water --- not constant. The bottle has three different areas which affect the height of water.

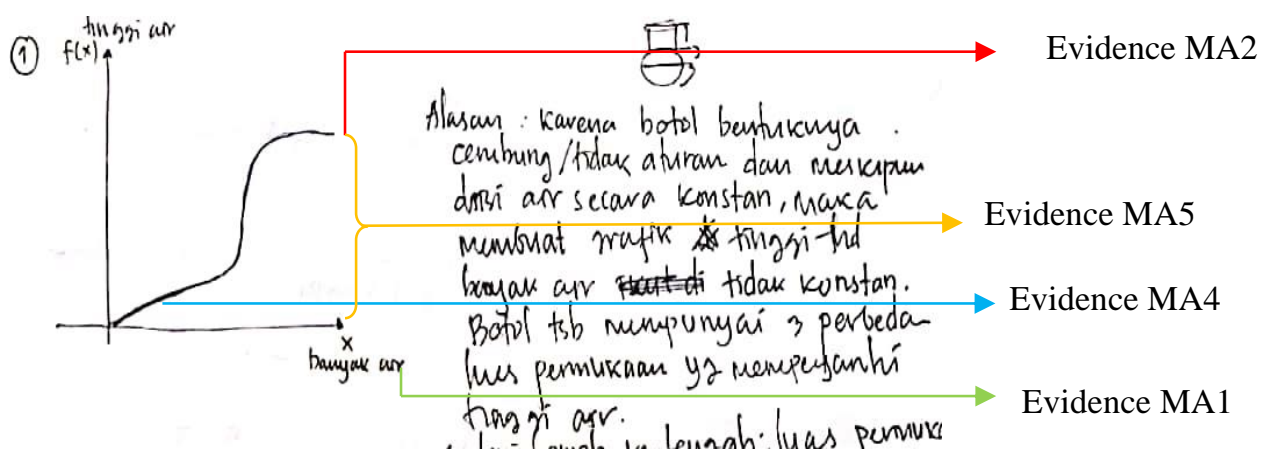

Figure 3. Subject B's graph on problem 1

Subject B's work on the graph (Figure 3) and interview (Transcript 3) on problem 1 unravel that she had claim in MA1, MA2, MA3, and MA4 of covariational reasoning. However, she could not demonstrate a claim in MA5. She also demonstrated reasoning in MA1, MA2, MA3, and MA4. Meanwhile, reasoning in MA5 did not emerge since his response to why the graph looks like smooth curve relates to the shape of the bottle, not the instantaneous rate of change of all domain of function as the reason for the smooth curve.

Figure 3 shows evidence in MA1, MA2, MA4, and MA5. MA3 was not identified. Even though she could point out where the change of water height occurs with her estimation, she did not make any point to mark the amount of change of water height. It is similar to the case of subject A, so MA4 and MA5 are not counted. 


\section{Translation}

The reason: because the bottle is concave/irregular and even though it is filled up with juice constantly, it makes a graph of juice height to the amount of juice not constant. The bottle has two different surface area which affects the height of the juice

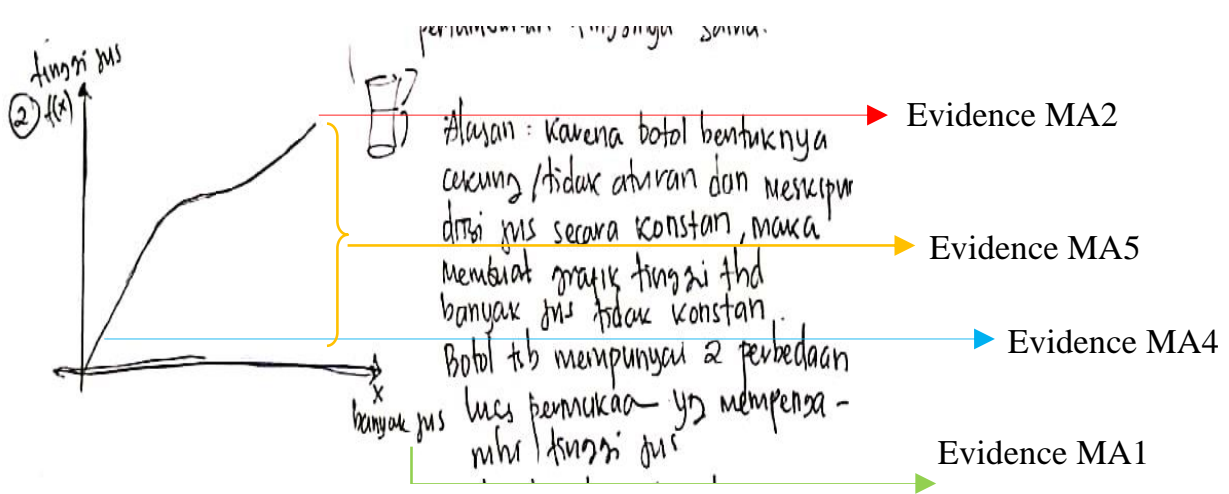

Figure 4. Subject B's graph on problem 2

Transcript 4 shows subject B's responses to his work on problem 2.

\section{Transcript 4}

$R \quad: \quad$ What do you know about the problem?

$B$ : The height of orange juice increases if the filling juice increase (Claim MA1). But, the increase of orange juice is affected by the shape of the glass (Claim MA3)

$R$ : What variable do you identify in the problem 2 to construct graph?

$B$ : The height of juice as $f(x)$ and the amount of juice as $x$ (Evidence MA1)

$R$ : Does the position of the two variables affect the graph? Explain!

$B$ : It does because in problem 2 it is clear that the height of juice is a function of the amount of juice. If the position is different, then what asked in the problem will be different (Reasoning MA1)

$R \quad:$ Why your graph goes upward?

$B$ : The volume of juice continuously added affect the height goes up (Claim MA2). This makes the graph goes upward (Reasoning MA2)

$R \quad$ : Which part of the graph showing the increasing height of orange juice?

$B$ : Maybe here (pointing to the part of the graph), but I should have made a point as I draw other common graphs of the function

$R$ : Why do you think a point in the graph could show the rate of change of the juice height?

$B$ : It is to make clear the rate of change in the juice height (Reasoning MA3)

$R$ : Considering the water which is filled up with the same amount, how it affects the height of juice?

$B$ : The rate of change of juice height will be different. From the bottom part to the middle, the rate of change is faster, and then it is getting slower when reaching the top of the glass (Claim MA4). This makes the graph has different gradients (Evidence MA4)

$R$ : Please, explain why your graph have different gradients like this? (Pointing to the difference in the gradient of the graph

$B$ : Maybe it is because the rate of change of juice height is different at the top. It relates to the different surface area of the glass (Reasoning MA4) 
$R \quad: \quad$ Why your graph looks like a smooth curve and has turning?

$B$ : The turning parts are affected by the shape of the glass (Reasoning MA3). For the curve, I just think that the graph should be like this.

Referring to the constructed graph (Figure 4) and transcript 4 for problem 2, subject B provided claim in MA1, MA2, MA3, and MA4. She could not give a proper statement relating to MA5. She also showed reasoning in MA1, MA2, MA3, and MA4. It was not found in MA5 since the subject experienced pseudo-reasoning (Vinner, 1997; Subanji, 2011) when explaining the smooth curve-shaped graph which has turning. The reasoning actually fit the criteria of MA3.

Figure 4 indicates evidence in MA1, MA2, MA4, and MA5. Evidence in MA3 was not identified since she could not show valid proof and the absence of points, although she was able to point out the amount of change of water height in the graph. It is similar to her case in problem 1 , so MA4 and MA5 are not counted.

Transcript 5 shows subject C's responses to his works on problem 1 (Figure 5).

$$
\begin{aligned}
& \text { Transcript } 5 \\
& R \text { : What variable do you identify in the problem } 1 \text { to construct graph? Explain the } \\
& \text { variables' position and relation! } \\
& C \text { : The height of the water as } y \text {-axis and the water volume as } x \text {-axis (Evidence }
\end{aligned}
$$

Subject C's works on the graph (Figure 5) and her responses in the interview (Transcript 5) indicate that he had claim in MA1, MA2, MA3, and MA4. The claim in MA5 of covariational reasoning could not be fulfilled since she could not provide statement pertaining to the instantaneous rate of change of all domain of a function in the decreasing interval. She also had reasoning in MA1, MA2, MA3, and MA4. The reason she explained relates to MA3, not MA5. She experienced pseudo-reasoning when giving an explanation regarding MA5. 


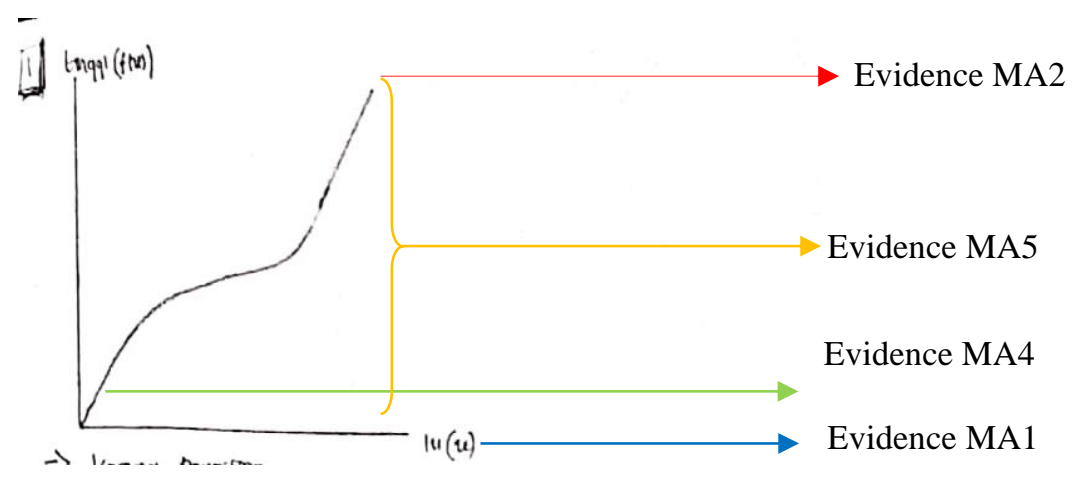

Figure 5. Subject C's graph on problem 1

Figure 5 indicates evidence in MA1, MA2, MA4, and MA5. The evidence in MA3 was not found since she only indicated the amount of height change using her estimation, not a point in the graph. It is similar to the case of subject A and B, so MA4 and MA5 are not counted.

Transcript 6 shows subject C's responses to her work on problem 2 (Figure 6).

\section{Transcript 6}

$R$ : What variable do you identify in the problem 1 to construct graph? Explain the variables' position and relation!

$C \quad$ : The volume of juice as input located in axis- $x$ and the height of juice as output in axis-y (Evidence MA1). The position is like that because juice height is the function of volume (Reasoning MA1). The relation is that the change of juice height is affected by the change of volume (Claim MA1)

$R$ : Could you explain the direction of graph considering the volume of juice which keep increasing?

$C \quad$ : The graph clearly goes upward (Claim MA2). This is because the volume of juice increases, and the height of juice also increase. So, no way the graph goes downward (Reasoning MA2)

$R$ : How the magnitude of the change of juice height when the juice is filled up with the same amount? Explain!

$C \quad$ : The magnitude of the change of juice height is affected by the surface area of glass (Claim MA3), the surface of the glass is not flat in all parts causes the magnitude of the change of height is different (Reasoning MA3)

$R$ : Could you point to the part of the graph which shows the amount of the change of height?

$C \quad:$ In this turning part

$R$ : How the rate of change of juice height as a result of the juice volume which is filled up with the same amount into the glass? Could you show it in your graph?

$C$ : The change rate is from slow to faster in the mid part of the glass, then becoming slower when reaching the top of the glass (Claim MA4). This is indicated by the graph which has different slopes

$R \quad$ : Why your graph looks like a smooth curve and has turning points?

$C \quad$ : Because of the different rate of change. It makes the graph has turning points (Reasoning MA4) 


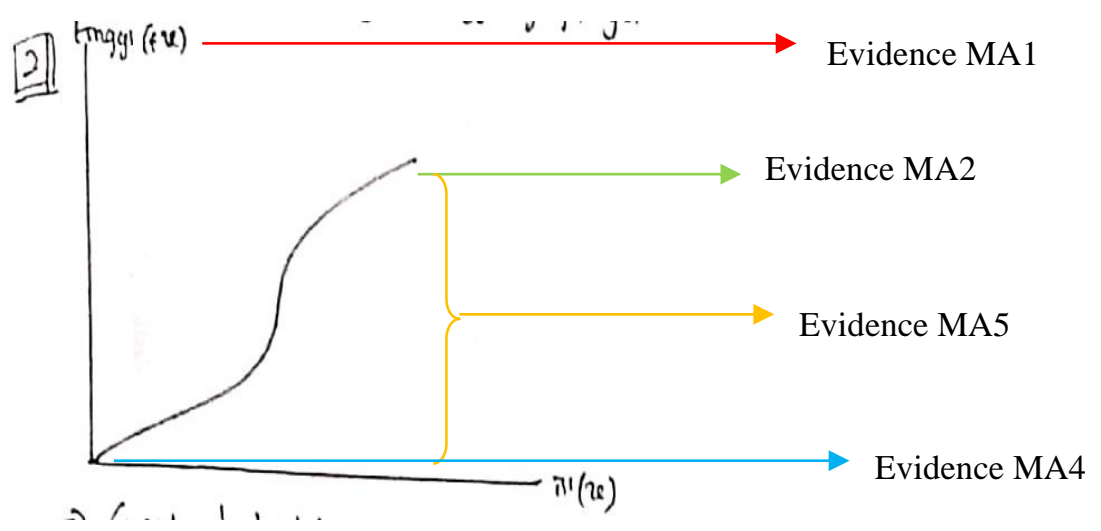

Figure 6. Subject C's graph on problem 2

Subject C's constructed graph (Figure 6) and transcript 6 unravel that she presented claim in MA1, MA2, MA3, and MA4. She also had reasoning in MA1, MA2, MA3, and MA4. She could not show reasoning in MA5 since she made equal the rate of change with the instantaneous rate of change.

Figure 6 indicates evidence in MA1, MA2, MA4, and MA5. Evidence in MA3 did not exist since she did not make a point to indicate the amount of rate change and was incorrect when explaining why the graph has turning part. It is similar to her case in problem 1, so MA4 and MA5 are not counted.

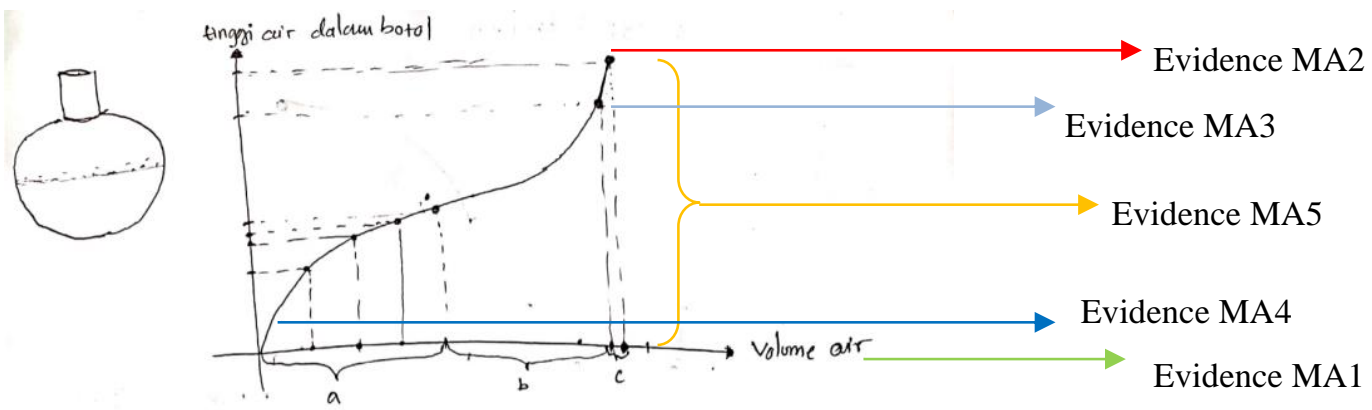

Figure 7. Subject D's graph on problem 1

Transcript 7 shows subject D's responses to his work on problem 1 (Figure 7).

\section{Transcript 7}

$R$ : What variable do you identify in the problem 1 to construct graph? Explain the variables' position and relation!

$D$ : The height and volume of water. The height of the water as function, $f(x)$, and the volume of water as $x$ (Evidence MA1). This position cannot be reversed since it will affect the graph (Reasoning MA1). The relation is that volume of water as an independent variable in which its change relates to the height of water (Claim MA1).

$R$ : If the volume of water keeps increasing, what happens to the graph?

$D$ : The graph goes upward (Claim MA2) like I made (Evidence MA2). It is not possible the graph goes to negative direction if the volume of water keeps increasing (Reasoning MA2) 
$R \quad$ : Could you explain the amount of change in water height when water is filled up into the bottle?

$D$ : For this, I do not know for sure because no numbers but I estimated by making points (evidence AM3) which later become interval to show the magnitude of change in water height (Reasoning MA3), and it is affected by the shape of the bottle which looks like a ball.

$R \quad$ : What can you tell about the result of water which is filled up continuously with the same amount?

$D$ : Filling up water with the same amount and continuously affect the difference in the rate of change of water height because the bottle is irregular (Claim MA4). This makes the graph has different slopes (Evidence MA4).

$R \quad$ : Why the graph has different slopes?

$D$ : Because at first, from bottom to mid part, the rate of change of water height become slower because the bottle is convex, then it becomes faster when reaching the top of the bottle and become constant when reaching the bottle cap (Reasoning MA4).

$R \quad: \quad$ Why does your graph look like a smooth curve?

$D$ : I just think the intervals I made will become smaller when the water is continuously filled up with the same amount into the irregular bottle (Claim MA5) like the graph I made (Evidence MA5). This might be the reason why the graph is like a smooth curve (Reasoning MA5)

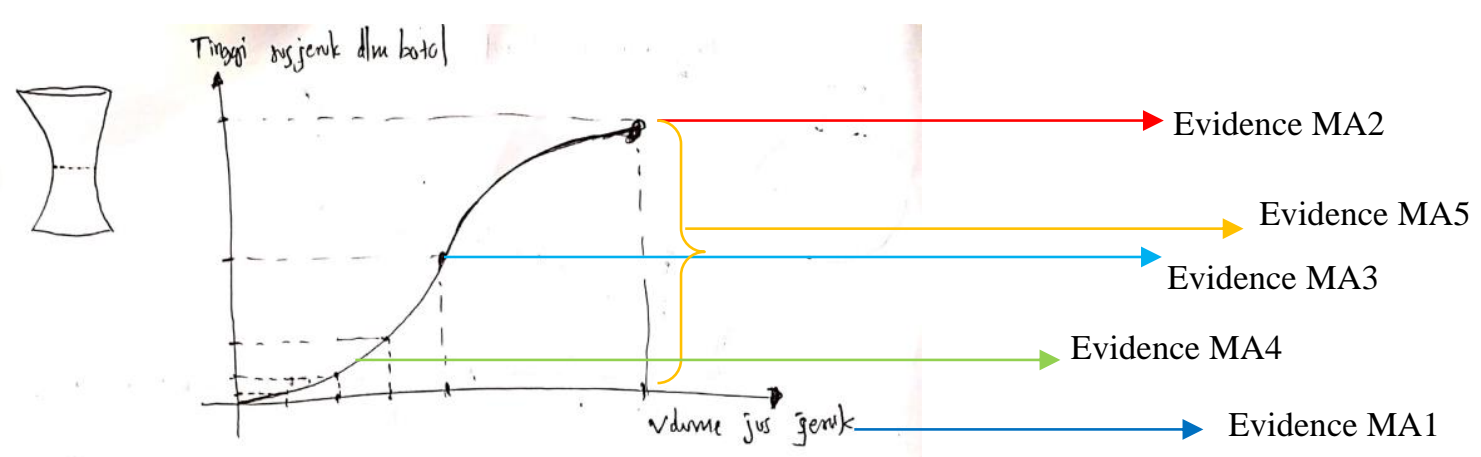

Figure 8. Subject D's graph on problem 2

Transcript 8 shows subject D's responses to his work on problem 2 (Figure 8).

\section{Transcript 8}

$R$ : What do you know about problem 2?

$D$ : I think this problem is similar to problem 1. The difference is the graph because the container is concave in the mid part, so the rate of change of juice height is faster when reaching the mid part and become slower when going to the top of the glass (Claim MA4). The variables are the same but with the different category: Height and volume of juice. I will have similar answers to problem 1 since they have identical concepts. 


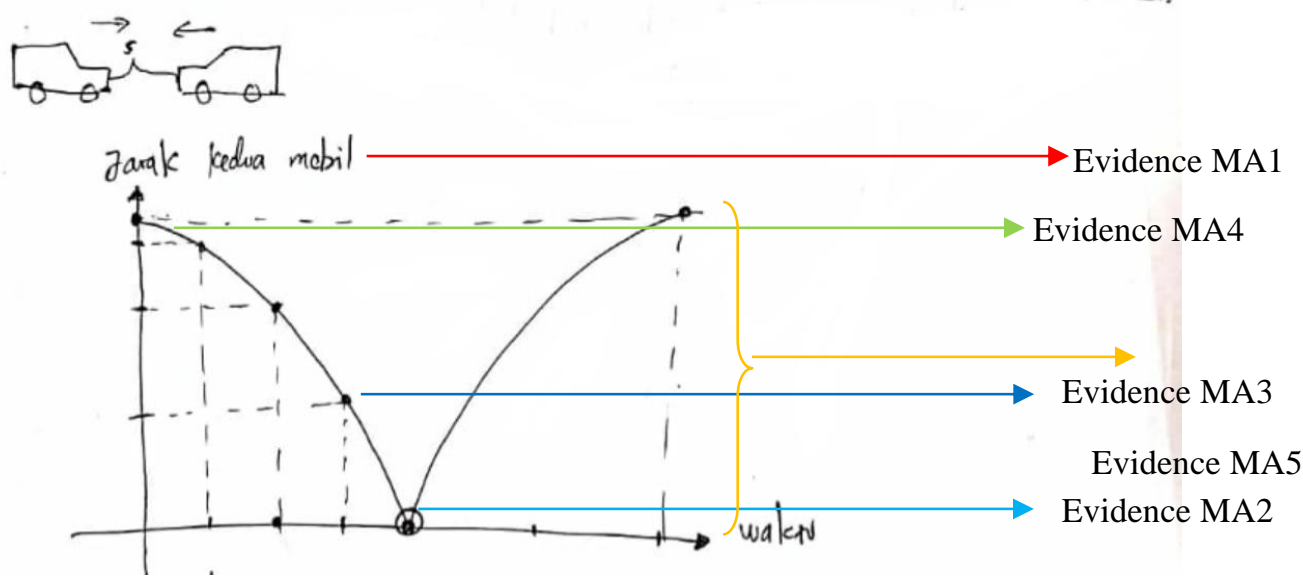

Figure 9. Subject D's graph on problem 3

Transcript 9 shows subject D's responses to his work on problem 3 (Figure 9).

\section{Transcript 9}

$R$ : What variable do you identify in the problem 1 to construct graph? Explain the variables' position and relation!

$D$ : The distance between two cars and time (Evidence MA1). Time as an independent variable because of the distance as the function (Reasoning MAl). The change of time affects the change of distance (Claim MA1)

$R$ : Could you explain the direction of change in your graph?

$D$ : When two cars came closer then passing through each other, the distance decreases. When the cars go away, the distance increases (Reasoning MA2), these make graph be concave in the downward direction as the result of the change of distance of the two cars (Claim MA2).

$R \quad: \quad$ What do the points mean in your graph?

$D$ : It is to provide a limit to the change in curvature of the graph caused by changes in the distance (Reasoning MA3). Time used by the cars before and after they pass through affects the magnitude of distance change because the speed is different (Claim MA3)

$R \quad:$ Why your graph is a bit curved?

$D$ : I think the changing speed of cars affect the rate of change of the distance between two cars (Claim MA4). This makes the change of distance is different caused by the different time to cover, which is faster before they pass through and slower after they pass through (Reasoning MA4). So, the graph is curved like this (Evidence MA4)

$R \quad: \quad$ Why does your graph look like a smooth curve?

$D$ : I just predict by following the intervals I made, but the intervals are less accurate. If it is accurate, with the decreasing interval, the graph will be smoother (Claim and Reasoning MA5).

Subject D's constructed graphs (Figure 7, Figure 8, Figure 9) and transcript 7-9 indicate that he had claim, evidence, and reasoning in all mental actions of covariational reasoning. He even realized the similarity of problem 1 and problem 2 , and the difference is only about the 
constructed graph and the rate of change of juice height. The student has been involved in mathematics Olympiad training and competition; thus, he is used to reasoning. This possibly makes his structure of argumentation differs from other students in this study.

We have presented students' constructed graphs and interviews and interpretations on students' argumentation (claim, evidence, reasoning) in mental actions of covariational when solving covariational problems. Table 3 summarizes the findings of the present study.

Table 3. Summarized findings on students' claim, evidence, and reasoning in mental actions of covariational reasoning

\begin{tabular}{ccccc}
\hline \multirow{2}{*}{ Subject } & Mental action & \multicolumn{3}{c}{ Argumentation } \\
\cline { 3 - 5 } & & Claim & Evidence & Reasoning \\
\hline A & MA1 & $\checkmark$ & $\checkmark$ & $\checkmark$ \\
& MA2 & $\checkmark$ & $\checkmark$ & $\checkmark$ \\
& MA3 & $\checkmark$ & - & $\checkmark$ \\
MA4 & $\checkmark$ & - & - \\
B & MA5 & - & - & $\checkmark$ \\
& MA1 & $\checkmark$ & $\checkmark$ & $\checkmark$ \\
& MA2 & $\checkmark$ & $\checkmark$ & $\checkmark$ \\
& MA3 & $\checkmark$ & - & $\checkmark$ \\
MA4 & $\checkmark$ & - & $\checkmark$ \\
& MA5 & - & - & $\checkmark$ \\
& MA1 & $\checkmark$ & $\checkmark$ & $\checkmark$ \\
& MA2 & $\checkmark$ & $\checkmark$ & $\checkmark$ \\
& MA3 & $\checkmark$ & - & $\checkmark$ \\
DA4 & $\checkmark$ & - & $\checkmark$ \\
& MA5 & - & $\checkmark$ & $\checkmark$ \\
\hline
\end{tabular}

Table 3 reveals that only one student who fulfil all mental actions of covariational reasoning in providing claim, evidence, and reasoning. Meanwhile, the other three students cannot reach mental action 5 in claim and reasoning and mental action 3 in evidence. The first student benefits from his experience in mathematics Olympiad. In the three students' claim, mental action 5 is not reached since they are not able to provide a proper statement about the instantaneous rate of change on the constructed graphs. This considerably relates to their understanding of the concept which is considered to be affected by students' lack of opportunity in the classroom to explore the concept of rate of change (Santoso et al., 2019).

On the other hand, mental action 3 of covariational reasoning could be fulfilled by the three students in evidence. Their constructed graphs show the amount of change of water or juice height without any points. Also, in the interview, they cannot justify the use of points to mark those changes. Moreover, they directly constructed the graph following the shape of the container. In this case, students' understanding is limited to the fact about the shape, which is considered as weak evidence (Faizah, Probosari, \& Karyanto, 2018). Umah et al. (2016) argue that the mental actions of covariational reasoning are a hierarchy. That is to say; higher mental actions will not emerge if the lower ones do not come out. In addition, Carlson et al. (2002) assert that to reach mental action 5, students shall fulfil all lower mental actions. Following this, 
evidence in mental action 4 and mental action 5 is not fulfilled. Although the students' graphs show different slopes as the evidence, it is not strong evidence since the basis for the graphs to have different slopes is the existence of points.

Besides the absence of mental action 5 in the claim, the three students also could not provide reasoning in mental action 5 . In this mental action, the students are expected to be able to relate their constructed smooth curve-shaped graphs to the idea of instantaneous rate of change of output variable as a result of the change of input variable withing decreasing interval. However, the students were just able to refer the graphs to the shape of the container and not able to differentiate the rate of change (mental action 3) and the instantaneous rate of change (mental action 5). Some students also experienced pseudo-reasoning (Vinner, 1997; Subanji, 2011) in explaining their graphs for mental action 5. This stage of mental action in reasoning is not easy for students to reach (Carlson et al., 2002). Unlike the olympiad student who reaches mental action 5 in reasoning, we think the other students have not got 'equal opportunity' in the mathematics classroom to understanding the concept of instantaneous rate of change. This seems to be the factor which makes them achieve differently.

We note that this study is limited to the students whose graphs meet the description of the mental actions of covariational reasoning (Table 1). In other words, the students who solve one problem or even could not solve the problems are not known yet about their argumentations. Furthermore, this study has not included rebuttal as the last component of argumentation proposed by McNeill and Krajcik (2011). Further studies are certainly needed to comprehensively understand the complete structure of all students' argumentation in covariational reasoning.

\section{Conclusion}

This study found that only one student fulfils five mental actions of covariational reasoning. Meanwhile, the other three students have similar components of argumentation which do not meet the mental actions. In providing the claim, the students can not reach mental action 5 (coordination of the instantaneous rate of change) since they are not able to provide a proper statement about the instantaneous rate of change on the constructed graphs. Similarly, when giving reasoning, the students are not able to come at the mental action 5 since they are unable to relate the idea of instantaneous rate of change to their smooth constructed graphs. For the evidence, the students can only fulfil mental action 1 and mental action 2 because of missing to construct any points as important evidence (mental action 3) to mark the amount of change in the graphs. This study, although only identify students' claim, evidence, and reasoning without rebuttal, provides insightful knowledge on the student's complete and incomplete argumentation in mental actions of covariational reasoning which support or hinder their ability in understanding the graph of a function.

\section{Acknowledgment}

The authors thank two anonymous reviewers for their constructive critics for this article. We also give special thanks to the editors who provide valuable assistance in the revision. The errors or inconsistencies found in this article remain our own. 


\section{References}

Aikenhead, G, S. (2005). Science-based occupations and the science curriculum: Concepts of evidence. Science education, 89(2). 242-275. Doi: 10.1002/sce.20046.

Baroody, A. J. (1993). Problem solving, reasoning, and communicating, (K-8): Helping children think mathematically. New York: Macmillan Publishing Company.

Berland, L. K., \& McNeill, K. L. (2010). A learning progression for scientific argumentation: understanding student work and designing supportive instructional contexts. Science Education, 94(5), 765-793, Doi: 10.1002/sce.20402

Carlson, M., Jacobs, S., Coe, E., Larsen, S., \& Hsu, E. (2002). Applying covariational reasoning while modelling dynamic events: A framework and a study. Journal for Research in Mathematics Education, 33(5), 352-378. Doi: 10.2307/4149958

Clement, J. (1989). The concept of variation and misconceptions in cartesian graphing. Focus on Learning Problems in Mathematics, 11(1-2), 77-87.

Confrey, J., \& Smith, E. (1994). Exponential functions, rate of change, and multiplicative unit. Educational Studies in Mathematics, 26(2/3), 135-164. Doi: 10.1007/BF01273661

Confrey, J., \& Smith, E. (1995). Splitting, covariation, and their role in the development of exponential functions. Journal for Research in Mathematics Education, 26(1), 66-86. Doi: 10.2307/749228

Cross, D., Taasoobshirazi, G., Hendricks, S., \& Hickey, D. T. (2008). Argumentation: A strategy for improving achievement and revealing scientific identities. International Journal of Science Education,30(6), 837-861. Doi: 10.1080/09500690701411567

Depdiknas. (2013). Permendiknas nomor 65 tahun 2013 tentang Standar Proses Pendidikan Dasar dan Menengah [The ministry of education's regulation on the standard process of primary and secondary education]. Jakarta: Depdiknas.

Faizah, L., Probosari, R. M., \& Karyanto, P. (2018). Penerapan problem-based learning untuk meningkatkan keterampilan argumentasi lisan siswa kelas XI pada pembelajaran biologi [Implementing problem-based learning to improve grade 11 students' verbal argumentation in biology]. Jurnal Biotek, 6(2), 1-12. DOI: 10.24252/jb.v6i2.6395

Fischer, F., Kollar, I., Ufer, S., Sodian, B., ... \& Eberle, J. (2014). Scientific Reasoning and Argumentation: Advancing an Interdisciplinary Research Agenda in Education. Frontline Learning Research, 2(3), 28-45. Doi: 10.14786/flr.v2i2.96

Heng, L. L., Surif, J. \& Seng, C. H. (2014). Individual versus group argumentation: Student's performance in a Malaysian context. International Education Studies,7(7), 109-124. Doi: 10.5539/ies.v7n7p109

Inglis, M., Mejia-Ramos, J. P., \& Simpson, A. (2007). Modelling mathematical argumentation: The importance of qualification. Educational Studies in Mathematics, 66, 3-21. Doi: 10.1007/s10649-0069059-8

Koklu, O. (2007). An investigation of college students' covariational reasonings. Florida: Florida State University.

Kusaeri, \& Aditomo, A. (2019). Pedagogical beliefs about critical thinking among Indonesian mathematics pre-service teachers. International Journal of Instruction, 12(1), 573-590. Doi: 10.29333/iji.2019.12137a

Kusaeri, Sutini, Suparto, \& Wardah, F. (2019). The validity and inter-rater reliability of project assessment in mathematics learning. Beta: Jurnal Tadris Matematika, 12(1), 1-13. Doi: 10.20414/betajtm.v12i1.266

McNeill, K. L., Lizotte, D, J., Krajcik, J., \& Marx, R. W. (2006). Supporting students' construction of scientific explanations by fading scaffolds in instructional materials. The Journal of the Learning Sciences, 15(2), 153-191. Doi: 10.1207/s15327809j1s1502_1

McNeill, K. L., \& Krajcik, J. (2008). Inquiry and scientific explanations: Helping students use evidence and reasoning. In J. Luft., R. L. Bell., \& J. Gess-Newsome (Eds.), Science as Inquiry in the Secondary Setting (pp.121-134). NSTA Press.

McNeill, K. L., \& Krajcik, J. (2011). Supporting grade 5-8 students in constructing explanation in science. London, UK: Pearson.

McNeill, K. L., \& Martin, D. M. (2011). Claims, evidence, and reasoning: Demystifying data during a unit on simple machines. Science and Children, 48(8), 52-56.

NCTM. (2000). Principles and standards for school mathematics. Reston, VA: NCTM. 
Pallant, A., \& Lee, H. (2015). Constructing scientific arguments using evidence from dynamic computational climate models. Journal of Science Education and Technology, 24(2-3), 378-395. Doi: 10.1007/s10956-014-9499-3

Rodriguez, J. M. G., Bain, K., Towns, M. H., Elmgren, M., \& Ho, F. M. (2019). Covariational reasoning and mathematical narratives: Investigating students' understanding of graph in chemical kinetics. Chemistry Education Research and Practice, 20(1), 107-119, Doi: 10.1039/c8rp00156a

Sadieda, L. U. (2019). Kemampuan argumentasi mahasiswa melalui model berpikir induktif dengan metode probing-prompting learning [Students' argumentation through inductive thinking model with probing-prompting learning]. Pythagoras: Jurnal pendidikan matematika, 14(1), 23-32. Doi: 10.21831/pg.v14i1.24038

Sadieda, L. U., Kusaeri, Lailiyah, S., \& Adaniyah, W. (2018). Exploring student's pattern generalisation strategy in solving the prism sticker problem. Beta: Jurnal Tadris Matematika,11(2), 131-143. Doi: 10.20414/betajtm.v11i2.174

Santoso, K, F., Budiarto, M. T., \& Sulaiman, R. (2019). Argumentation in covariational reasoning: Middle school student's solving covariation problem with different cognitive style. Paper presented at International Conference of Science, Technology, Education, Arts, Culture and Humanity. Interdisciplinary Challenges for Humanity Education in Digital Era (STEACH 2018). Doi: 10.2991/steach-18.2019.6

Slavitt, D. (1997). An alternative route to the reification of function. Educational Studies in Mathematics, 33, 259-281. Doi: 10.1023/A:1002937032215

Soekisno, R. B. A. (2015). Pembelajaran berbasis masalah untuk meningkatkan kemampuan argumentasi matematis mahasiswa [Problem-based learning to improve students' argumentation in mathematics]. Infinity, 4(2), 120-139. Doi: 10.22460/infinity.v4i2.77

Stewart, J. (2008). Calculus: Early transcendentals (Seventh edition). New York: Cengage Learning.

Subanji, S. (2006). Berpikir pseudo penalaran kovariasional dalam mengonstruksi grafik fungsi kejadian dinamik: Sebuah analisis berdasarkan kerangka kerja VL2P dan implikasinya pada pembelajaran matematika [Pseudo-covariational reasoning in constructing the graph of function of dynamic event: An analysis based on VL2P framework and its implication in mathematics learning]. Jurnal Ilmu pendidikan, 13(1), 1-9.

Subanji. (2011). Teori berpikir pseudo penalaran kovariasional [The theory of pseudo-covariational reasoning]. Malang: UM Press.

Thompson, P. W., \& Carlson, M. P. (2017). Variation, covariation, and functions: Foundational ways of thinking mathematically. In J. Cai (Ed.), Compendium for Research in Mathematics Education (pp. 421-456). Reston, VA: National Council of Teachers of Mathematics.

Thompson, P. W. (1996). Imagery and the development of mathematical reasoning. In L. P. Steffe, B. Greer, P. Nesher, P. Cobb, \& G. Goldin (Eds.), Theories of Learning Mathematics (pp.267-283). Hillsdale N J: Erlbaum.

Toulmin, S. E. (2003). The uses of argument. Cambridge: Cambridge University Press.

Umah, U., As'ari, A. R., \& Sulandra, I. M. (2016). Struktur argumentasi penalaran kovariasional siswa (The argumentation structure of students' covariational reasoning), JMPM: Jurnal Matematika dan Pendidikan Matematika, 1(1), 1-12. Doi: 10.26594/jmpm.v1i1.498

Vinner, S. (1997). The pseudo conceptual and the pseudo analytical thought processes in mathematics learning. Educational Studies in Mathematics, 34(2), 97-129. Doi: 10.1023/A:1002998529016

Zeytun, A. S., Cetinkaya, B., \& Erbas, A. K. (2010). Mathematics teachers' covariational reasoning levels and predictions about students' covariational reasoning abilities. Educational Sciences: Theory \& Practice, 10(3), 1601-1612. 